\title{
Production of Protein Hydrolysate from Rohu (Labeo rohita) Waste using Fungal Proteases
}

\author{
Masood Sadiq Butt ${ }^{1}$, Sadia Aslam ${ }^{1,2}$, Rizwan Shukat ${ }^{1, *}$, Syed Qamar Abbas ${ }^{1}$, \\ Muhammad Issa Khan ${ }^{1}$, Shadab Shaukat ${ }^{3}$ and Muhammad Shahid ${ }^{4}$ \\ ${ }^{1}$ National Institute of Food Science and Technology, Faculty of Food, Nutrition \\ and Home Sciences, University of Agriculture, Faisalabad \\ ${ }^{2}$ School of Food and Agricultural Sciences, University of Management and \\ Technology, Lahore \\ ${ }^{3}$ Faculty of Agriculture, University of Agriculture, Faisalabad \\ ${ }^{4}$ Department of Biochemistry, Faculty of Sciences, University of Agriculture, \\ Faisalabad
}

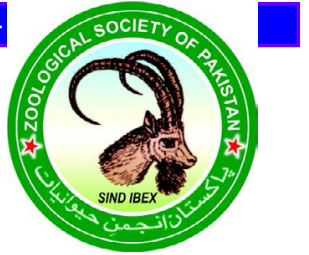

Article Information

Received 23 July 2019

Revised 23 May 2020

Accepted 01 February 2021

Available online 26 May 2021

Authors' Contribution

MSB and RS planned the research

and analyzed the data. SA conducted

the research and performed the

experiments. SA and SS wrote the

manuscript. RS, SQA, MIK and MS supervised the research.

Key words

Labeo rohita, Protein hydrolysate,

Proteases, Fish proteins, Amino acids.

\section{INTRODUCTION}

$\mathrm{T}$ he world fish production is increasing at $6.6 \%$ rate annually and currently stands at 174 million. Share of fisheries is significant in GDP i.e. $0.41 \%$. Total fish production of Pakistan is 0.47 million metric (GoP, 201718). Due to increased production of fish in oceans and fish farms, its utilization has also increased in fish based dishes.

Rohu fish (Labeo rohita) belongs to the family Cyprinidae and order Cypriniformes. It is inhabited in the rivers of subcontinent (Talwar and Jhingran, 1991). Rohu fish culture is being reared in semi-intensive, full-size systems in ponds and low-lying regions of Pakistan.

Fish waste is considered as garbage of no financial value (Gildberg and Stenberg, 2001). 25\% of the total fish production is estimated to be discarded as a waste annually (Rustad, 2003). Skin, bones, head, scales and viscera are fish wastes (Benjakul and Morrisey, 1997). Fish waste

\footnotetext{
Corresponding author: rizwan.shukat@uaf.edu.pk 0030-9923/2021/0004-1373 \$ 9.00/0

Copyright 2021 Zoological Society of Pakistan
}

contains appreciable amount of protein (Kristinsson and Rasco, 2000). Waste of fish industry, if not properly processed may be the root cause of health, environmental and economic issues (Vidotti et al., 2003). Value of the fish proteinaceous waste can be increased by transforming it into protein hydrolysate (Aspmo et al., 2005).

Response surface methodology (RSM) is a statistical tool commonly used to optimize the complicated processes and employ quantitative information from the experimental layout to deduce and instantly resolve problems involving two or more variable quantities. Likewise degree of hydrolysis is the fraction of proteins hydrolyzed at equilibrium. Hydrolysis could be enzymatic or chemical.

The enzymatic processing of protein can be performed under regulated conditions of $\mathrm{pH}$ and temperature using proteases from microbial or plant sources (Shahidi et al., 1995). Flavorzyme is a fungal peptidase obtained from Aspergillus oryzae and performs well at $\mathrm{pH} 7$ and temperature $50^{\circ} \mathrm{C}$.

Enzymatic hydrolysis and solubilization of proteins from different origins has been investigated extensively 
by many authors (Aspmo et al., 2005). Flavorzyme is used for protein hydrolysis to produce bioactive peptides with suitable functional characteristics (Kristinsson and Rasco, 2000). Amiza et al. (2011) optimized the enzymatic hydrolysis conditions for preparation of protein hydrolysate from silver catfish and recommended hydrolysis for 134 min at $58^{\circ} \mathrm{C}$ temperature and substrate $\mathrm{pH} 9.4$ and $8.3 \%$ of enzyme to substrate concentration. Current study was designed to optimize the experimental conditions through the application of response surface methodology for the production of protein hydrolysate from fish waste using flavorzyme protease.

\section{MATERIALS AND METHODS}

Rohu (Labeo rohita) fish was procured from local fish market of Faisalabad (Punjab, Pakistan). Fish waste such as skin, head, tail and fins of fish were removed to serve as raw material for this experiment. Fish waste was grinded to obtain the mince and then packed in polyethylene bags and stored at $-18^{\circ} \mathrm{C}$ for further use. The proteolytic enzyme flavorzyme used for fish protein hydrolysis was procured from Novozymes A/S (Bagsvaerd, Denmark). All the chemicals required for this research were procured from Sigma Aldrich (Germany).

\section{Composition analysis of fish waste}

Moisture, ash, crude fat and crude protein contents of minced fish waste were determined by the methods outlined by AOAC (2002).

\section{Extraction and quantification of soluble fish proteins}

A chemical method was used for the extraction of soluble fish proteins as described by Arnesen and Gildberg (2005). Rohu fish waste ( $2 \mathrm{~kg}$ ) was homogenized in 2000 $\mathrm{mL}$ of water. The $\mathrm{pH}$ of the blend was maintained at 11 with inclusion of $62 \mathrm{~mL}$ of $3 \mathrm{M} \mathrm{NaOH}$ solution. In first step sample mixture was centrifuged at $4000 \mathrm{~g}$ for $15 \mathrm{~min}$ at $4^{\circ} \mathrm{C}$. Afterwards supernatant was separated and pellet was suspended in $2 \mathrm{~L}$ of distilled water and $15 \mathrm{ml}$ of 3 molar $\mathrm{NaOH}$ solution was added to maintain the $\mathrm{pH}$ at 11 . The second step of protein extraction was conducted for $1 \mathrm{~h}$ and the sample was centrifuged again at similar parameters as in previous step. Again, supernatant was collected and pellet was dissolved in $2 \mathrm{~L}$ of water, $145 \mathrm{~mL} \mathrm{HCl}$ was used to adjust the $\mathrm{pH}$ at 2 . The pellet was again dissolved in $2 \mathrm{~L}$ of distilled water and the $\mathrm{pH}$ was regulated to 2 using 3 molar $\mathrm{HCl}$ solution $(145 \mathrm{~mL}$ ) before centrifugation for 15 min. All these supernatants from the three extractions were pooled together. $\mathrm{pH}$ of the resultant blend was adjusted at 7 by adding 3 molar $\mathrm{NaOH}$ solution. The samples were placed at room temperature to precipitate for $15 \mathrm{~min}$ and the soluble fraction of protein was obtained by centrifuge at $5000 \mathrm{~g}$ for $60 \mathrm{~min}$ at $4^{\circ} \mathrm{C}$ (at $\left.\mathrm{pH} 7\right)$.

Protein concentration determination in fish protein extract was performed using kjeldhal method as described by AOAC (2002).

\section{Enzymatic hydrolysis of fish proteins}

The extracted protein solution was hydrolyzed by using the flavourzyme enzyme. The hydrolysis reaction was carried out in water bath shaker at $150 \mathrm{rpm}$ using flavorzyme enzyme under conditions as provided in Table I. After completion of hydrolysis time, sample was heated at $100^{\circ} \mathrm{C}$ for $10 \mathrm{~min}$ to discontinue the reaction. Centrifugation of sample was performed at $4{ }^{\circ} \mathrm{C}$ and $4100 \mathrm{rpm}$ for $40 \mathrm{~min}$ to get soluble hydrolysate. Protein hydrolysates was collected as the supernatant, lyophilized and stored at $-40^{\circ} \mathrm{C}$ prior to analysis.

Table I.- Independent factors and coded design levels used in RSM studies for flavorzyme.

\begin{tabular}{lccc}
\hline Factors & \multicolumn{3}{c}{ Levels } \\
\cline { 2 - 4 } & $\mathbf{- 1}$ & $\mathbf{0}$ & $+\mathbf{1}$ \\
\hline $\mathrm{pH}$ & 5.0 & 6.5 & 8.0 \\
Temperature $\left({ }^{\circ} \mathrm{C}\right)$ & 40 & 45 & 50 \\
E/S ratio $(\mathrm{W} / \mathrm{W})$ & 1.5 & 2.0 & 2.5 \\
Time $($ Min $)$ & 60 & 90 & 120 \\
\hline
\end{tabular}

The software Design Expert (Trial version 11 Stat-Ease Inc., NY, USA) was used for designing the experimental model and data analysis via execution of response surface methodology (RSM). The four explanatory variables were used in this experiment including temperature (A), time of hydrolysis (B), [E]/[S] (C) and $\mathrm{pH}(\mathrm{D})$, while response variable was $\mathrm{DH}(Y)$. Different coded values of explanatory variables are depicted in Table I. A central composite design (CCD) was applied with 30 exploratory runs including sixteen full factorial points, seven replicates of central points and seven axial points. The fitness of statistical model was studied by applying the following quadratic equation:

$$
Y=b o+\sum_{i=1}^{3} b_{i} X_{i}+\sum_{i=1}^{3} b_{i i} X_{i}^{2}+\sum_{i<j}^{3} b_{i j} X_{i} X_{j}
$$

Where, $Y$ indicates the response variable, $b_{o}$ represent the intercept while $b_{i}, b_{i i}$, and $b_{i j}$ were symbolized for the coefficients of linear, quadratic and interaction terms whereas $X_{i}$ and $X_{j}$ indicate the independent variables, respectively.

Predicted values were calculated and compared with 
the experimental values to validate the model. Regression model was statistically tested by Fisher's test for ANOVA to assess the statistical momentousness of the regression coefficients. 3D response surface plots were depicted by Design Expert (DE) software version 11 to demonstrate the relationship between different levels of the independent and dependent variables.

Supplementary Table I shows actual and predicted values of $\mathrm{DH}(\%)$ of rohu fish protein hydrolysate by flavorzyme and Supplementary Table II shows analysis of variance (ANOVA) for the quadratic response surface model for DH using flavorzyme.

Table II.- Suggested/predicted conditions for degree of hydrolysis (DH) of Rohu fish protein using Flavorzyme by Design expert software.

\begin{tabular}{lcccccc}
\hline No. & Temp & Time & E/S ratio & pH & DH (Y1) & Desirability \\
\hline 1 & 60.00 & 120 & 2.5 & 8.50 & 55.70412 & 1 \\
2 & 59.99 & 113.74 & 2.34 & 8.50 & 52.89567 & 1 \\
3 & 59.99 & 106.39 & 2.35 & 8.50 & 52.42623 & 1 \\
4 & 59.99 & 111.60 & 2.41 & 8.49 & 53.73986 & 1 \\
5 & 59.99 & 110.67 & 2.49 & 8.49 & 55.1911 & 1 \\
6 & 59.99 & 96.92 & 2.46 & 8.49 & 53.14002 & 0.99 \\
7 & 59.99 & 112.52 & 2.49 & 8.40 & 55.22382 & 0.99 \\
8 & 59.99 & 111.51 & 2.34 & 8.50 & 52.70548 & 0.99 \\
9 & 59.99 & 93.78 & 2.45 & 8.49 & 52.5067 & 0.99 \\
10 & 59.99 & 103.70 & 2.366 & 8.50 & 52.40 & 0.99 \\
\hline
\end{tabular}

This analysis of degree of hydrolysis (DH) was conducted by following the procedure (Adler-Nissen 1979; Aslam et al., 2020). A hydrolyzed $125 \mathrm{mg}$ sample was added in $25 \mathrm{~mL}$ of $1 \%$ SDS solution. The solution was warmed in water bath for $15 \mathrm{~min}$ at $50^{\circ} \mathrm{C}$ and later cooled to room temperature. The sample $(250 \mu \mathrm{L})$ was added in $2 \mathrm{ml}$ of 0.2 molar phosphate buffer to adjust the $\mathrm{pH}$ at 8.2 and heated at $50^{\circ} \mathrm{C}$ for $1 \mathrm{~h}$ in water bath. The $\mathrm{pH}$ was lowered by using $4 \mathrm{ml}$ of 0.1 molar $\mathrm{HCl}$ to discontinue the reaction. The sample was stored for $30 \mathrm{~min}$ at $25^{\circ} \mathrm{C}$ and spectrophotometric absorbance was estimated at 340 nm via VU-VIS spectrophotometer (CECIL-CE7200). A standard curve of L-leucine was used to quantify the DH applying the given formula:

$$
\% D H=\frac{X_{1} \times 14.007 \times V_{1} \times D \times 100}{W \times V_{2} \times 10000}
$$

Where, $X_{1}$ is $\eta$ mol of leucine read out from the standard leucine curve, $\mathrm{V} 1$ is volume of the sample used $(25 \mathrm{~mL})$, $\mathrm{D}$ is dilution factor, $\mathrm{W}$ is mass of the sample, and V2 is volume used for the reaction.
Freeze drying of fish protein hydrolysates

Protein hydrolysates with highest DH were selected and freeze dried. The samples were loaded to the trayed bottles and frozen at $-40^{\circ} \mathrm{C}$ and allowed to stand at this temperature for $1 \mathrm{~h}$. Pressure was maintained at 200 $\mathrm{mL}$ and temperature was raised up to $-15^{\circ} \mathrm{C}$ for primary drying. Primary drying was carried out for overnight then products were subjected to secondary drying at $20^{\circ} \mathrm{C}$ for 2 h. Final products were obtained in the form of crystalline white powder with greenish tinge.

\section{Amino acid profiling of protein hydrolysate}

The amino acid profile of fish protein hydrolysates prepared through enzymatic hydrolysis was conducted using amino acid analyzer (Waters, USA). The protocol followed was elucidated by Ghosh et al. (1997) using Pico. Tag column $(3.9 \mathrm{~mm} \times 15 \mathrm{~cm})$ and work station. Eighteen amino acids were detected which were Ala, Arg, Asp, Cys, Glu, Gly, His, Ile, Leu, Lys, Met, Phe, Pro, Ser, Thr, Trp, Tyr and Val. A protein sample $(20 \mathrm{mg})$ was hydrolyzed with hydrochloric acid $(6 \mathrm{~N})$ for $24 \mathrm{~h}$ at $24^{\circ} \mathrm{C}$. Hydrolyzed samples were neutralized by sodium hydroxide solution $(6 \mathrm{~N})$. Derivatization of the samples was carried out by phenyl isothiocyanate (PITC) solution at $25^{\circ} \mathrm{C}$ for $20 \mathrm{~min}$. Afterwards, samples were injected in to high performance liquid chromatography (HPLC 1525, Waters) at $38^{\circ} \mathrm{C}$ provided with fluorescence detector and reversed phase column as mentioned in Pico Tag manual. Amino acids present in hydrolyzed protein samples were calculated quantitatively by comparing with retention time and peak areas of amino acids against standards.

For the determination of the tryptophan, samples were mixed with $100 \mathrm{~mL}$ of sodium hydroxide solution (4.2M) and $0.3 \mathrm{~mL}$ of triglycerine at $\mathrm{pH}$ 5.0. Quantification of tryptophan was performed at wavelength of $400 \mathrm{~nm}$ by colorimetric analysis (Deng et al., 2002). Chemical scores of flavorzyme prepared hydrolysates was determined by following the equation mentioned by Nilsang et al. (2005) regarding essential amino acid content in reference protein as per FAO/WHO (1991).

Chemical score $=\frac{\text { Essential amino acid content in test protein }(\mathrm{gm} / 100 \mathrm{gm})}{\text { Essential amino acids in standard protein }(\mathrm{gm} / 100 \mathrm{gm})}$

\section{RESULTS AND DISCUSSION}

Composition of minced rohu fish waste products (head, tail, skin, frames and fins) shows that moisture content for rohu (Labeo rohita) waste was $78.18 \%$. The range of moisture content was in corroboration with the findings of Dhanapal et al. (2013). Results also showed that crude fat, ash and crude protein content of initial raw material was $1.41 \%, 1.2 \%$ and $18.39 \%$, respectively. The 
protein content in fish waste was in line with the previous results outlined by other investigators (Azizah et al., 2001; Bhaskar and Mahendrakar, 2008). It was also found in literature that protein content of fish muscles is between $5-20 \%$, but in some species it varies from 5-28\% (Murray and Burt, 2001).

In rohu fish protein extract the crude protein content was $11.40 \pm 0.025 \%$ and concentration of true protein was $10.54 \pm 0.01 \%$. The current results are comparable to the results obtained by Batista et al. (2009) who found the $17 \%$ and $9 \%$ protein content for hake fish and monk fish waste, respectively.

Figure 1 shows two major bands at approximately 30 and $35 \mathrm{KDa}$ which correlate the findings of Reed and Park (2008).

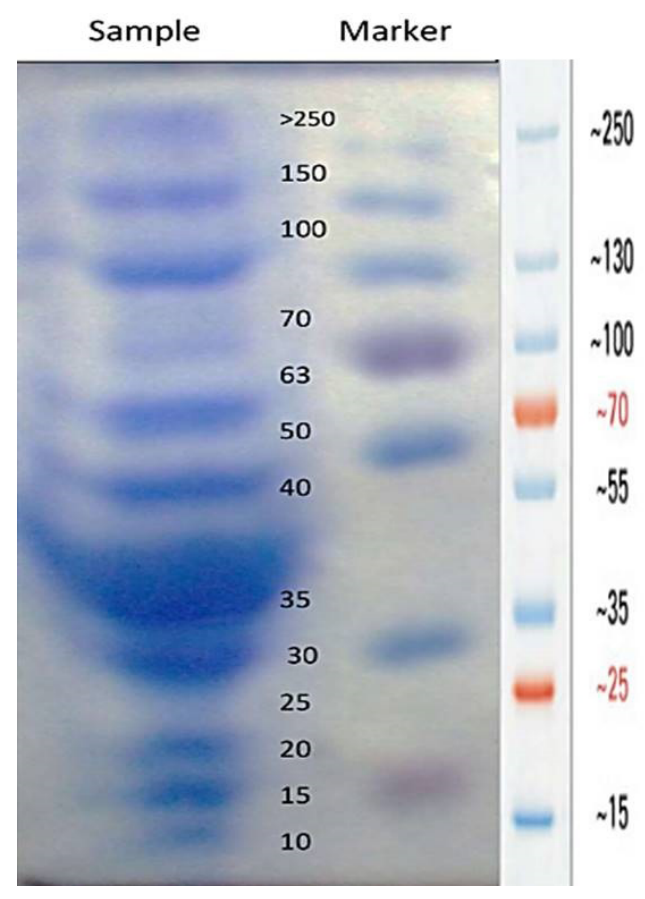

Fig. 1. SDS-PAGE of fish protein extract.

The results about actual and predicted values of DH $(\%)$ of rohu fish protein hydrolysate by flavorzyme shows that maximum degree of hydrolysis $(50.49 \%)$ was at temperature $50^{\circ} \mathrm{C}$ after $120 \mathrm{~min}, \mathrm{E} / \mathrm{S} 2.5 \%$ and $\mathrm{pH}=8$ and the conditions of the least $\mathrm{DH}(14.36 \%)$ were at temperature $40^{\circ} \mathrm{C}$, time of hydrolysis $60 \mathrm{~min}, \mathrm{E} / \mathrm{S} 1.5$ $\%$ and $\mathrm{pH}=5$, respectively. Little difference was observed between actual and predicted values of $\mathrm{DH} \%$ which suggested the high validity of the experimental model to the estimated response variables.

Analysis of variance (ANOVA) for the quadratic response surface model for $\mathrm{DH}$ using flavorzyme demonstrate that the F-value of model was 26.41 which showed the high significance of experimental model. It implied that there was only a $0.01 \%$ possibility that high value of Fisher's test (26.41) could appear. ANOVA for DH of fish protein using flavorzyme revealed that experimental model was highly significant at a $99 \%$ confidence interval. The F-value of lack of fit was 4.62 which implied that there was a $5.24 \%$ chance that a large F-value (4.62) of "lack of fit" could appear due to error. The $\mathrm{R}^{2}$ (Coefficient of determination) value was $96.10 \%$ indicating that this statistical model could express the actual relationship between selected parameters very well and only $4.90 \%$ of total variation cannot express the $\mathrm{DH}$ of fish protein by flavorzyme. The adjusted $\mathrm{R}^{2}$ for $\mathrm{DH}$ by flavorzyme was $92.46 \%$ and predicted $\mathrm{R}^{2}$ was $80.73 \%$. The Predicted $\mathrm{R}^{2}$ of 0.8073 was in appropriate harmony with the adjusted $\mathrm{R}^{2}$ of 0.9246 because the variation between them was below 0.2 . In this experiment standard deviation and coefficient of variation were 2.85 and 9.725 , respectively which indicates that there were low chances of error to occur in this experiment.

The following second order polynomial equations express the dependence of degree of hydrolysis on the independent variables. The response surface regression equation generated by the RSM for flavorzyme enzyme can be explained as following:

$$
\begin{gathered}
\mathrm{Y}(\mathrm{DH})=30.58+5.09 \mathrm{~A}+4.07 \mathrm{~B}+2.08 \mathrm{C}+9.90 \mathrm{D}- \\
0.53 \mathrm{AB}+0.14 \mathrm{AC}+2.65 \mathrm{AD}+0.03 \mathrm{BC}+1.97 \mathrm{BD}+ \\
0.36 \mathrm{CD}-7.76 \mathrm{~A}^{2-} 2.10 \mathrm{~B}^{2}+2.49 \mathrm{C}^{2}+5.30 \mathrm{D}^{2}
\end{gathered}
$$

Equations indicated that highest value of estimated regression coefficients were for $\mathrm{pH} 9.9$ using flavorzyme. It can be deduced from the equation that $\mathrm{pH}$ is the most important explanatory variable having strong influence on response variable i.e. DH. These findings are in corroboration with the result mentioned by Nilsang et al. (2005). Adequate precision for this experiment was 20.96. Adequate precision determines the experimental signal to noise ratio and a ratio higher than 4 is required. All independent factors temperature, time of hydrolysis, $[\mathrm{E}] /[\mathrm{S}]$ and $\mathrm{pH}$ had significant $(\mathrm{p}<0.01)$ independent and linear effect on degree of hydrolysis of Rohu fish protein hydrolysate using flavorzyme enzyme at $99 \%$ confidence interval. The interaction terms temperature-pH (AD) and time of hydrolysis-pH (BD) had significant $(\mathrm{p}<0.05)$ effect on degree of hydrolysis for flavorzyme at $95 \%$ confidence interval. Other interaction terms such as temperaturetime of hydrolysis (AB), temperature-[E]/[S] (AC), time of hydrolysis-[E]/[S] (BC) and $[\mathrm{E}] /[\mathrm{S}]-\mathrm{pH}(\mathrm{CD})$ had no momentous $(\mathrm{P}>0.05)$ impact on $\mathrm{DH}$ of fish protein for flavorzyme enzyme. 

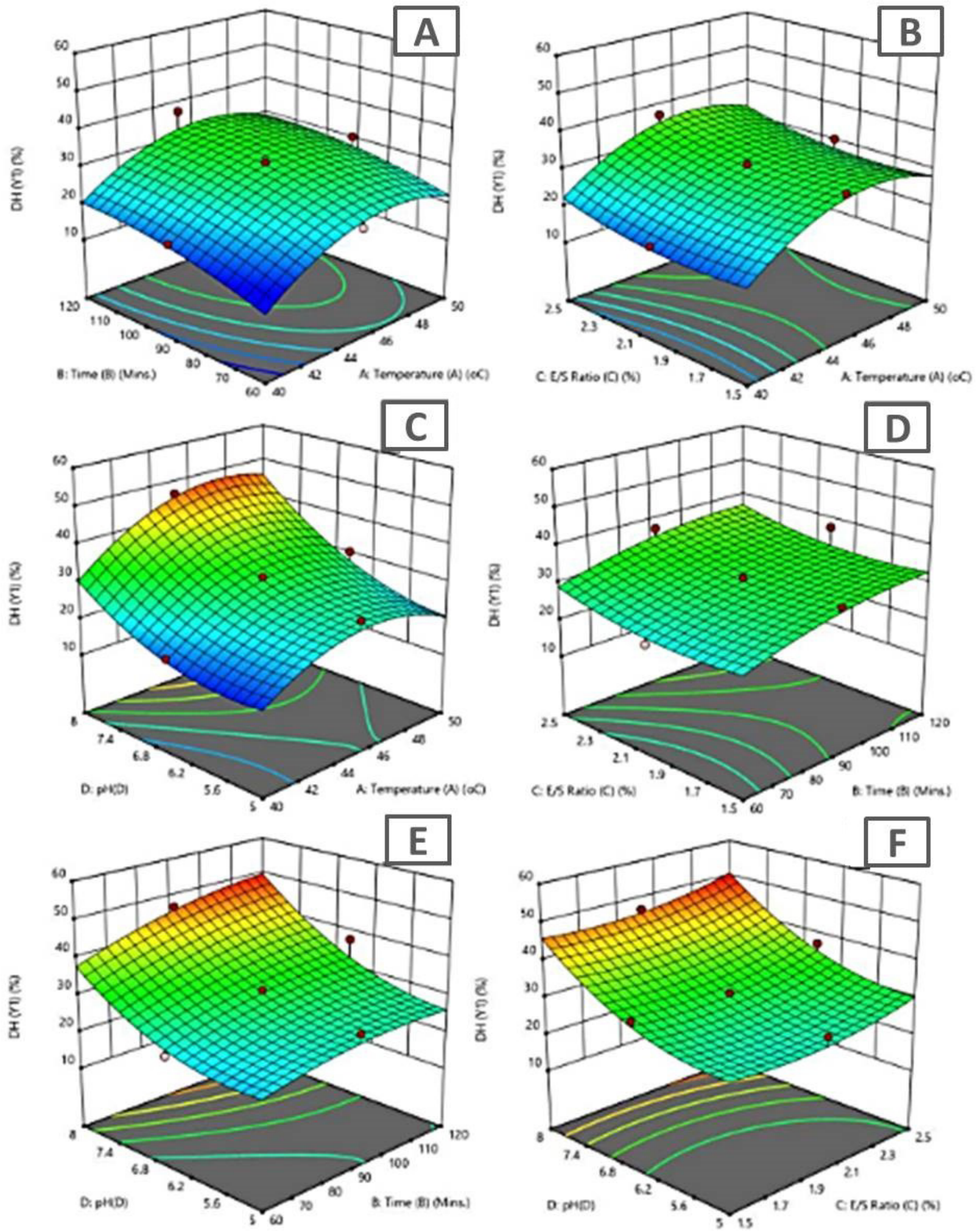

Fig. 2. RSM 3D graphs for $\mathrm{DH}$ using flavorzyme as a function of (A) time and temperature. $\mathrm{B}, \mathrm{E} / \mathrm{S}$ ratio and temperature. C, temperature and $\mathrm{pH}(\mathrm{D})$ time and $\mathrm{E} / \mathrm{S}(\mathrm{E}) \mathrm{pH}$ and time (F) $\mathrm{E} / \mathrm{S}$ and $\mathrm{pH}$. 
The interaction influence of the explanatory variable on the $\mathrm{DH}$ using flavorzyme are demonstrated through three-dimensional response surface graphs (Fig. 2A-F). Figure 2A shows the interaction effect of temperature and time of hydrolysis of flavorzyme on degree of hydrolysis. The result accomplished that the DH improved with the increasing the temperature and time of hydrolysis because enzyme activity is improved with increasing the reaction time. Figure 2B show the impact of temperature and $[\mathrm{E}] /$ [S] (AC) on DH for flavorzyme while keeping the impact of $\mathrm{pH}$ and time of hydrolysis fixed. It can be concluded from the results that the higher concentration of $\mathrm{E} / \mathrm{S}$ would have a positive effect on $\mathrm{DH}$ while decrease of $\mathrm{E} / \mathrm{S}$ ratio made the decrease in DH for flavorzyme enzyme. In the presence of higher number of enzymes molecules there will be more chances of proteolytic reaction to occur. At higher enzyme concentration, large number of enzyme molecules became integrated with the protein molecules thus liberating the peptides of lower molecular weight in the system. These outcomes are in harmony with the results described by Normah et al. (2005) for the optimum enzyme concentration for fish protein hydrolysis. Figure $2 \mathrm{C}$ demonstrates the impact of $\mathrm{pH}$ and temperature on $\mathrm{DH}$ for flavorzyme while keeping the impact of time and $[\mathrm{E}] /[\mathrm{S}]$ as constant. Increase in temperature and $\mathrm{pH}$ had positive impact on DH. Enzyme activity upgraded with increasing the temperature up to its optimum temperature. Results are not surprising because optimum $\mathrm{pH}$ for flavorzyme is 5-8. Figuer 2D shows the impact of hydrolysis time and $[\mathrm{E}] /[\mathrm{S}]$ on $\mathrm{DH}$. Increase in time of hydrolysis had positive influence on $\mathrm{DH}$. With the increase in $[\mathrm{E}] /[\mathrm{S}]$ ratio efficiency of the hydrolysis reaction also increased. Figure 2E demonstrates the effect of time of hydrolysis and $\mathrm{pH}$. Increase in time of hydrolysis and $\mathrm{pH}$ had positive impact on $\mathrm{DH}$ for flavorzyme. Interaction effect of $\mathrm{BD}$ was significant $(\mathrm{p}<0.05)$. Figure $2 \mathrm{~F}$ show the influence of $[\mathrm{E}] /[\mathrm{S}]$ and $\mathrm{pH}$ on $\mathrm{DH}$ for flavorzyme. $[\mathrm{E}] /[\mathrm{S}]$ and $\mathrm{pH}$ had positive impact on response variable. Quadratic term $\mathrm{A}^{2}$ had highly significant $(\mathrm{p}<0.01)$ effect on $\mathrm{DH}$ at $99 \%$ confidence interval and $\mathrm{D}^{2}$ had significant $(\mathrm{p}<0.05)$ impact on DH for flavorzyme at $95 \%$ confidence interval. Other quadratic terms such as $\mathrm{B}^{2}$ and $\mathrm{C}^{2}$ had no momentous impact ( $\mathrm{p}>0.05)$ on $\mathrm{DH}$ for flavorzyme enzyme.

The optimal reaction conditions for different explanatory variables were determined by using 'Numerical Optimization' of the Design-Expert11 software. The optimum reaction conditions for $\mathrm{DH}$ using flavorzyme enzyme were temperature $46.37^{\circ} \mathrm{C}$, time of hydrolysis $116.91 \mathrm{~min},[\mathrm{E}] /[\mathrm{S}] 1.97 \%$ and $\mathrm{pH}$ of 7.99 and that the DH was predicted to be $50.78 \%$.

Table II shows suggested values of DH by DesignExpert Software version 11 for flavorzyme. Desirability profiles (if 1 or closer to 1) showed that the experimental specifications were most appropriate to achieve the optimum DH. To examine the precision of the predicted model, hydrolysis experiments under the resulted optimum conditions were carried out and $\mathrm{DH}$ for flavorzyme was found $50.13 \%$. The optimum conditions for this study were in compliance with the results mentioned by Bhaskar et al. (2008) for hydrolysis of fish waste proteins using proteolytic enzymes and Amiza et al. (2013) for silver catfish waste.

The compositional analysis was performed for final product (lyophilized rohu fish protein powder). Lyophilized rohu protein powder was developed by using the specifications of hydrolysis reaction that was provided with the highest degree of hydrolysis i.e. The highest DH using Flavorzyme, $50.49 \%$ was obtained at temperature $50^{\circ} \mathrm{C}$, time of hydrolysis $120 \mathrm{~min}, \mathrm{E} / \mathrm{S} 2.5 \%$ and $\mathrm{pH}=8$.

The results about compositional analysis for fish protein powder prepared using flavorzyme showed that moisture content was $7.86 \%$, protein content was $72.55 \%$, ash content $11.42 \%$ and fat content $0.43 \%$. In this research the protein content of rohu fish protein hydrolysate powder was higher as compared to tilapia protein hydrolysate powder (37.7-49.6\%) as reported by Azizah et al. (2001), Catla protein hydrolysate $(14.25 \%)$ as suggested by Bhaskar et al. (2008) and was in line with the mackerel, white croaker and sardine protein hydrolysates (82.7$85.1 \%$ ) as reported by Arvanitoyannis and Kassaveti (2013). Thiansilakul et al. (2008) mentioned that round scad fish protein hydrolyzed using flavorzyme yielded $69 \%$ of protein.

Table III shows amino acid composition of freezedried fish protein powder prepared by flavorzyme. The results showed that the Histidine $(1.98 \pm 0.03)$, isoleucine (3.05 \pm 0.03$)$, leucine $(6.93 \pm 0.08)$, lysine $(6.26 \pm 0.07)$, methionine (1.96 \pm 0.05$)$, phenylalanine (3.02 \pm 0.05$)$, tryptophan $(0.29 \pm 0.01)$, threonine $(3.54 \pm 0.07)$ and valine $(4.07 \pm 0.05)$ tended to be predominate in protein hydrolysate prepared by flavorzyme assisted hydrolysis. The current results are in line with the results described by Satya and Dora (2011) who revealed that concentration of the amino acids increases with increase in DH. To estimate the nutritional value of protein hydrolysates prepared by using protease its chemical scores was calculated on the basis of reference protein. Tryptophan is present in least amount while lysine was present in excess in flavorzyme based hydrolysate while other essential amino acids were present in adequate quantity. The amino acid profile of protein hydrolysate in current study were in harmony with the findings of Benjakul and Morrisey (1997) who studied the amino acid profile of pacific whiting waste. 
Table III.- Mean values for essential amino acids and chemical score of fish protein hydrolysates.

\begin{tabular}{lcc}
\hline $\begin{array}{l}\text { Essential } \\
\text { amino acids }\end{array}$ & $\begin{array}{c}\text { Amino acid } \\
\text { concentration (\%) }\end{array}$ & $\begin{array}{c}\text { Chemical } \\
\text { score }\end{array}$ \\
\hline Histidine & $1.98 \pm 0.03$ & 0.99 \\
Isoleucine & $3.05 \pm 0.03$ & 0.84 \\
Leucine & $6.93 \pm 0.08$ & 0.99 \\
Lysine & $6.26 \pm 0.07$ & 1.13 \\
Methionine & $1.96 \pm 0.05$ & 0.56 \\
Phenylalanine & $3.02 \pm 0.05$ & 0.70 \\
Tryptophan & $0.29 \pm 0.01$ & 0.24 \\
Valine & $4.07 \pm 0.05$ & 0.75 \\
Threonine & $3.54 \pm 0.07$ & 0.88 \\
Non-essential amino acids & \\
Arginine & $7.03 \pm 0.02$ & - \\
Alanine & $8.71 \pm 0.04$ & - \\
Aspartic acid & $8.48 \pm 0.02$ & - \\
Serine & $4.40 \pm 0.01$ & - \\
Cystine & $0.10 \pm 0.001$ & - \\
Glutamic acid & $10.07 \pm 0.01$ & - \\
Glycine & $21.22 \pm 0.05$ & - \\
Proline & $7.74 \pm 0.03$ & - \\
Tyrosine & $0.86 \pm 0.01$ & - \\
Arginine & $7.03 \pm 0.02$ & \\
\hline
\end{tabular}

Mean values of 3 determinations \pm standard deviation.

It can be inferred from the mean values for nonessential amino acids that in protein hydrolysate prepared by flavorzyme cysteine was the limiting amino. In flavorzyme based protein hydrolysate the most abundant amino acids were glycine (21.22 \pm 0.05$)$, glutamic acid $(10.07 \pm 0.01)$ and aspartic acid $(8.48 \pm 0.02)$. Bhasker et al. (2008) reported the higher concentration of aspartic acid and glutamic acid in protein hydrolysate from catla fish waste using commercial protease. The results regarding amino acid composition of current study are in corroboration with the results of Roslan et al. (2014) who described the amino acid profile of tilapia muscle protein hydrolysate. Present findings are also in line with the results of See et al. (2011).

\section{CONCLUSION}

Fungal protease i.e. flavorzyme enzyme was quite efficient for the hydrolysis of fish proteins. The degree of hydrolysis of rohu fish protein was significantly influenced by reaction conditions such as temperature, $\mathrm{pH}$, time of hydrolysis and $[\mathrm{E}] /[\mathrm{S}]$. The optimized conditions for the production of protein hydrolysate were temperature $46.37^{\circ} \mathrm{C}$, time of hydrolysis $116.91 \mathrm{~min},[\mathrm{E}] /[\mathrm{S}]$ ratio $1.97 \%$ and $\mathrm{pH}$ of 7.99 to get the degree of hydrolysis close to $50.78 \%$. It was also concluded that response surface methodology may provide most suitable and economic processes to produce fish protein hydrolysates. Protein hydrolysate in powder form was developed from rohu fish waste with high protein concentration $(72.55 \%)$ and rich amino acid score. Fish protein hydrolysate has a good potential to be used as food additive. The hydrolyzed proteins and peptides of small size has great utilization due to their enhanced and improved functional characteristics. Thus, production of fish protein hydrolysate is an effective alternative utilization of fish industrial waste and opportunity for fish processors to get more profit. Further studies to evaluate the functional properties of fish hydrolysates will pave the way towards novel innovation in protein hydrolysis.

\section{ACKNOWLEDGEMENTS}

Authors acknowledge the financial support provided by Higher Education Commission Govt. of Pakistan (grant number 315-15854-2AV3-086). Author Sadia Aslam thanks the National Institute of Food Science and Technology, University of Agriculture Faisalabad, Pakistan for analytical services rendered by them.

\section{Supplementary material}

There is supplementary material associated with this article. Access the material online at: https://dx.doi. org/10.17582/journal.pjz/20190723040754

\section{Statement of conflict of interest}

The authors have declared no conflict of interests.

\section{REFERENCES}

Adler-Nissen, J., 1979. Determination of the degree of hydrolysis of food protein hydrolysate by trinitrobenzensulfonic acid. J. Agric. Fd. Chem., 27: 1256-1262. https://doi.org/10.1021/jf60226a042

Amiza, M.A., Nurul Ashikin, S. and Faazaz, A.L., 2011. Optimization of enzymatic protein hydrolysis from silver catfish (Pangasius sp.) frame. Int. Fd. Res. J., 18: 775-78.

Amiza, M.A., Ow, Y.W. and Faazaz, A.L., 2013. Physicochemical properties of silver catfish (Pangasius sp.) frame hydrolysate. Int. Fd. Res. J., 20: $1255-1262$.

AOAC, 2002. Official methods of analysis, $17^{\text {th }}$ ed. 
Association of Official Analytical Chemists, Washington, USA.

Arnesen, J.A. and Gildberg, A., 2007. Extraction and characterization of gelatine from Atlantic salmon (Salmo salar) skin. Bioresour. Technol., 98: 53-57. https://doi.org/10.1016/j.biortech.2005.11.021

Arvanitoyannis, I.S. and Kassaveti, A., 2008. Fish industry waste: Treatments, environmental impacts, current and potential uses. Int. J. Fd. Sci. Technol., 43: 726-745. https://doi.org/10.1111/j.13652621.2006.01513.x

Aslam, S., Shukat, R., Khan, M.I. and Shahid, M., 2020. Effect of dietary supplementation of bioactive peptides on antioxidant potential of broiler breast meat and physicochemical characteristics of nuggets. Fd. Sci. Anim. Resourc., 40: 55-73. https:// doi.org/10.5851/kosfa.2019.e82

Aspmo, S.I., Horn, S.J. and Eijsink, V.G.H., 2005. Enzymatic hydrolysis of Atlanic cod (Gadus morhua L.) viscera. Process Biochem., 40: 1957-1966. https://doi.org/10.1016/j.procbio.2004.07.011

Azizah, A.H., Jamilah, B. and Gan, H.B., 2001. Nutritional quality of spray dried protein hydrolysate from Black Tilapis (Oreochromis mossambicus). Fd. Chem., 78: 69-74. https://doi. org/10.1016/S0308-8146(01)00380-6

Batista, I.., Ramos, C., Mendonca, R. and Nunes, M.L., 2009. Enzymatic hydrolysis of sardine (Sardina pilchardus) by-products and lipid recovery. $J$. aquat. Fd. Prod. Technol., 18: 120-134. https://doi. org/10.1080/10498850802581823

Benjakul, S. and Morrisey, M.T., 1997. Protein hydrolysate from pacific whiting solid waste. $J$. Agric. Fd. Chem., 61: 131-138.

Bhaskar, N. and Mahendrakar, N.S., 2008. Optimization of enzymatic hydrolysis of visceral waste proteins of Catla (Catla catla) for preparing protein hydrolysate using a commercial protease. Bioresour. Technol., 99: 4105-4111. https://doi.org/10.1016/j. biortech.2007.09.006

Deng, S.G., Peng, Z.Y., Yang, P. and Xia, X.Z., 2002. Application of multi-enzymatic method in fermented fish sauce production from Harengula zunasi's offal. Fd. Ferment. Indust., 28: 32-36.

Dhanapal, K., Saravani, K. and Balasubramanian, A. and Reddy, G.V.S., 2013. Quality determination of rohu (Labeo rohita) during ice storage. Tamilnadu J. Vet. Anim. Sci., 9: 146-152.

FAO/WHO, 1991. Protein quality evaluation: Report of the Joint FAO/WHO Expert Consultation. Food and Nutrition Paper 51, FAO, Rome.

Ghosh, A.K., Naskar, A.K. and Sengupta, S., 1997.
Characterization of a xylanolytic amyloglucosidase of Termitomyces clypeatus. Biochim. biophys. Acta, 1339: 289-296. https://doi.org/10.1016/ S0167-4838(97)00011-3

Gildberg, A. and Stenberg, E.A., 2001. A new process for advanced utilization of shrimp waste. Process Biochem., 36: 809-812. https://doi.org/10.1016/ S0032-9592(00)00278-8

GoP, 2017-2018. Pakistan economic survey. Economic Advisor's Wing, Finance Division, Islamabad.

Kristinsson, H.G. and Rasco, B.A., 2000. Biochemical and functional properties of Atlantic Salmon (Salmo salar) muscle hydrolyzed with various alkaline protease. J. Agric. Fd. Chem., 24: 177-187. https:// doi.org/10.1111/j.1745-4514.2000.tb00694.x

Murray, J. and Burt, J.R., 2001. The composition of fish. Torry Advisory Note No. 38, Ministry of Technology, Torry Research Station, U.K., pp. 14.

Nilsang, S., Lertsiri, S., Suphantharika, M. and Assavanig, A., 2005. Optimization of enzymatic hydrolysis of fish soluble concentrate by commercial protease. J. Fd. Eng., 70: 571-578. https://doi.org/10.1016/j.jfoodeng.2004.10.011

Normah, I., Jamilah, B., Saari, N. and Che Man Yaakob, B., 2005. Optimization of hydrolysis conditions for the production of threadfin bream (Nemipterus japonicus) hydrolysate by Alcalase $\AA$. J. Muscle Fds., 16: 87-102. https://doi.org/10.1111/j.17454573.2005.07404.x

Reed, Z.H. and Park, J.W., 2008. Qualification and quantification of fish protein in prepared surimi crabstick. J. Fd. Sci., 73: 329-334. https://doi. org/10.1111/j.1750-3841.2008.00759.x

Roslan, J. Kamal, S.M.N., Yunos, K.F.M. and Abdullah, N., 2014. Optimization of enzymatic hydrolysis of tilapia (Orechomis niloticus) muscles using response surface methodology. Sains Malysiana, 43: 17151723.

Rustad, T., 2003. Utilization of marine byproducts. Elec. J. Environ. Agric. Fd. Chem., 2: 458-463.

Satya, S.D. and Dora, K.C., 2011. Optimization of the production of shrimp waste protein hydrolysate using microbial proteases adopting response surface methodology. J. Fd. Sci. Technol., 51: 1624. https://doi.org/10.1007/s13197-011-0455-4

See, S.F., Hoo, L.L. and Babji, A.S., 2011. Optimization of enzymatic hydrolysis of Salmon skin by alcalase. Int. Fd. Res. J., 18: 1359-1365.

Shahidi, F., Han, X.Q. and Synowiecki, J., 1995. Production and characteristics of protein hydrolysates from capelin (Mallotus villosus). Fd. Chem., 53: 285-293. https://doi.org/10.1016/0308- 
8146(95)93934-J

Talwar, P.K. and Jhingran, A.G., 1991. Fisherine status and their link between sediment CNP content of Kadinamkulam Estuary at Kerala, India. Oxford and IBH Publishing Co. Pvt. Ltd., New Delhi, pp. 1097.

Thiansilkalu, Y., Benjakul, S. and Shahidi, F., 2007. Functional properties and antioxidative activity of protein hydrolysate from round scad (Decapterus maruadsi). Fd. Chem., 103: 1385-1394. https://doi. org/10.1016/j.foodchem.2006.10.055

Vidotti, R.M., Viegas, E.M.M. and Careiro, D.G., 2003. Amino acid composition of processed fish silage using different raw materials. Anim. Feed Sci. Technol., 105: 199-204. https://doi.org/10.1016/ S0377-8401(03)00056-7 